Spatial and Temporal Analysis of Crude Oil Theft in the Niger Delta

Tahir Ngada and Kate Bowers ${ }^{1}$

Department of Security and Crime Science, UCL.

${ }^{1}$ Corresponding author k.bowers@ucl.ac.uk

UCL Department of Security and Crime Science

University College London

35 Tavistock Square

London

WC1H 9EZ 


\title{
Spatial and Temporal Analysis of Crude Oil Theft in the Niger Delta
}

\begin{abstract}
This research sought to investigate patterns and correlates of the under-researched crime of crude oil theft (COT) in the context of the Niger Delta. The aim was to examine the feasibility of opportunity-, deprivation- and market-value-based explanations for COT patterns. A total of 1039 incidents of COT recorded by the Nigerian Oil Producers' Trade Section in 2012-2014 were analysed. The results indicate that even when controlling for clustering of the oil pipeline infrastructure, spatial clustering of COT was statistically significant indicating manipulation of vulnerable situational contexts. No significant correlation was found between COT and the local unemployment or poverty rate. Finally, there was a moderate, significant positive temporal association between the volume of crude oil stolen and the international market price. The findings provide evidence that COTs are likely perpetrated by rationally motivated offenders and suggest that situational crime prevention and market reduction approaches show promise in proactively curtailing criminal opportunities.
\end{abstract}

Key words: Crude Oil Theft; spatial clustering; hot products; situational prevention; market reduction approaches. 


\section{Introduction}

The empirically underexplored crime of crude oil theft (COT), which is billed as an organised crime associated with oil exploration and extraction, occurs in a number of locations worldwide, but in the research undertaken in this paper is conducted within the particular context of the Niger Delta region of Nigeria. To demonstrate the extent of the problem in this location, according to the country's former finance minister, the menace culminates in losses of about $\$ 12$ billion annually (Okonjo-Iweala, 2014). Unfortunately, the problem persists despite efforts by government and oil companies to assuage the perceived causes and influencing factors of the crime (Watts, 2007; Oluwaniyi, 2011; Renouard and Lado, 2012). COT is neither a ubiquitous phenomenon in all the oilfields, nor is it randomly distributed; rather, it clusters at specific 'hot spots' and also demonstrates varying patterns over time. There are a number of explanations for the existence of these clusters including temporal and geographic variation in socio-political and economic factors and patterns in the manifestation of opportunities for this type of theft. This paper examines the spatial and temporal pattern of COT in the Niger Delta, tests the viability of these alternative explanations and then discusses the implications that the results have for the practice of reducing theft of this type.

\section{Crude Oil Theft in Context}

Extraction of crude oil in the Niger region is enabled by a network of onshore oil wells, pipelines and flow stations located in the creeks of the mangrove forests. These onshore oil infrastructures are connected through pipelines to export terminals and offshore oil platforms. According to Nigeria's Department of Petroleum Resources (DPR), there are currently about 2,800 oil wells connected to 130 flow stations in 218 oil fields (DPR, 2015). 
Transportation of extracted crude oil is through a largely vulnerable 4,441 km pipeline network (DPR, 2015). To a certain extent, the locations of the oil infrastructure exposes them to disruption through perennial vandalism. This is mostly because criminals exploit the existing infrastructure by breaching oil pipelines, and siphoning crude oil for sale on the international black market or for local unconventional artisanal refining (Onuoha, 2007). The international black market for stolen crude oil is speculated to be underpinned by demands for cheap oil by certain foreign refining businesses seeking to maximise profits through transnational organised criminality (Asuni, 2009).

The swamps of the Niger Delta mangrove forest make mass COT possible in two principal ways. First, offenders bore holes into any portion of the vulnerable pipelines and siphon oil onto floating storages such as propelled wooden boats or towed barges (Katsouris and Sayne, 2013). These are either transferred further offshore onto larger ocean carrier vessels or locally refined. A second method is for offenders to insert hoses into pipelines to siphon oil directly into large storage boats that can navigate in ultra-shallow waters. Thereafter, stolen products are transferred directly into larger carrier vessels which are anchored offshore (Katsouris and Sayne, 2013). These acts cumulatively amount to product losses of about 400,000 barrels per day as noted by the Vice President of Nigeria (Kayode, 2015).

\section{Socio-political factors influencing Crude Oil Theft}

Collier (2008) traces the root causes of resource related delinquencies, such as COT, in poorer countries to defective political economics of resource exploitation. The solution to these problems, according to Collier (2008), lie in public policy instruments such as economic restructuring and/or political reforms. Similarly, Davis (2009) and Obi (2010) contend that problems in resource exploitation culminated into political violence in the 1990s, which 
exacerbated COT within the Niger Delta. Onuoha (2008) however, argues that COT is not a direct product of socio-political problems because it had long existed before the surge in political violence, and it only became worrisome due to increasingly high theft volumes. Ikelegbe (2005) integrates these ideas and concludes that COT might be spurred by local politicians seeking to empower their supporters while also reaping some financial benefits in the process.

Other perspectives by Ufuoma and Omoruyi (2014) contend that motivation for COT might be based on moral justification. This is largely attributable to beliefs that multinational oil companies and the government seek to exploit their natural resources at the expense of the local population. As a result, those with such dispositions do not consider COT to be a crime, but rather a morally justified action. It follows that those under the most stress are likely to succumb to the view that such theft is acceptable. This delinquent behaviour is similarly explained by Sykes and Matza (1957), who suggest that such criminal dispositions are underpinned by "unrecognised extension of defences to crimes in the form of justifications for deviance that are valid by the delinquent" (p.666). These defences according to Sykes and Matza (1957), are operationalised as techniques of neutralisation which manifest by persons involved in COT denying any responsibility for their action, or even believing that their behaviour does not result in any significant harm. They further see themselves as avengers who justify their acts by repressing their wrongdoings through a belief that those who condemn them have motives and intentions that are against them.

In terms of demographic factors, Onuoha (2009); Garuba (2010), as well as Oteh and Eze (2012), argue in favour of the view that high unemployment and poverty ratios, as well as poor standards of living, are associated with COT. Relatedly, Asuni (2009) also believes that 
poverty-related issues need to be addressed, but concede that COT is not likely to be entirely motivated by poor socioeconomic conditions. As a consequence of considering the social, economic and political factors, Watts (2009) and Davidheiser and Nyiayaana (2011), among others, believe that the solution to COT lies in ameliorating the distal socio-political causes.

\section{Economic Influences on Crude Oil Theft}

COT has been characterised as being very probably influenced by the international market price of the commodity which incentivise and motivate theft syndicates (Asuni, 2009). Despite research on how the crime is carried out (Ikelegbe, 2005; Davis, 2009; Garuba, 2010; Obi, 2010; Katsouris and Sayne, 2013), little focus has been given on how market prices might be influencing it. However, research on the impact of market value on similar crimes- and thefts in particular- has been conducted. Sutton's (1995) proposed that "if more goods are being stolen then more stolen goods are being bought" (p.400) and argues that many acquisitive crimes would not occur if offenders did not believe in the marketability of their stolen products (Sutton, 1995).

A few studies have found a link between markets and levels of theft. Stevenson et al (2001) found evidence in support of an association between markets for stolen items and the attendant supply and found minimal hindrances in trading of stolen items in either legitimate or illegitimate markets. Sidebottom et al (2011) examined the connections between metal price and metal theft found strong evidence in support of a positive association between copper theft in the UK and copper prices. They also note that copper theft levels are not statistically associated with general theft patterns and unemployment rates in the UK. Posick et al (2012) also found a similar relationship between prices of metals and copper theft from April 2008 to July 2010 in Northeast, United States. Sidebottom et al (2014) observe that 
often, a high level of risk taking is required to steal copper cables implying that the crime is the tradecraft of rationally motivated predatory offenders, who are conscious of the value of the goods on offer. Interestingly, such risk is like those taken by crude oil thieves (Katsouris and Sayne, 2013), and in both cases, the perceived benefits are more likely to outweigh the costs when the market value is high as proposed by the rational choice perspective of offending behaviour (Clarke and Cornish, 1985).

Where economic explanations hold, Sutton et al (2001), as well as Sutton and Simmonds (2004) advocate the use of 'market reduction approaches' (MRA) in disconnecting markets for illicit items and their supply. Through lack of evaluation studies, there is currently only limited empirical support for this approach, but what is available shows some promise. Ashby and Bowers (2015) found a significant positive association between the location of scrap markets and areas with high levels of metal theft, which implies that shutting down the local market for scrap metal should reduce theft levels. Researching on a different type of desirable good, Schneider (2008) concluded from evaluative research that MRA had assisted in curtailing illicit trade in endangered wildlife. However, given the nature of the market for crude oil, one issue with the applicability of the MRA is the structure of the buyer network. Unlike a large network of scrap dealers who are not necessarily specific in what they will buy, agents buying crude oil are likely to be limited in number and more specialist to begin with.

\section{Opportunity-based explanations of Crude Oil Theft patterns}

It is now well established that crime clusters and that it is not evenly distributed across people (either victims or offenders), products or places and times (e.g. Johnson, 2010). For example, Sherman et al (1989) demonstrated that $4 \%$ of the addresses in Minneapolis accounted for $53 \%$ of the calls of police service in a one-year time frame. These intensive concentrations of 
crime are caused at least in part by the ease with which the crimes can be undertaken and it has been shown that there is a strong association between the amount of offending and the vulnerability of the targets that are available (Clarke, 2005). There is a large body of research in support of opportunity-based explanations, and offences that show a high degree of concentration over space and time are likely to be at least partially dependent on opportunity structure.

In line with the opportunity explanation, studying the characteristics of targets that are highly susceptible to theft enables the categorization of the most attractive ones as 'hot products' (Clarke, 1999). Clarke (1999) submits that such products are sought after because they are concealable, removable, available, valuable, enjoyable and eventually disposable (CRAVED). This framework guides the investigation of a broad range of CRAVED product thefts like timber theft in the southern Appalachian region (Baker, 2003), parrot poaching in Mexico (Pires and Clarke, 2012) and livestock theft in Malawi (Sidebottom, 2013). The categorisation of crude oil as a CRAVED product is yet to be researched comprehensively. However, Katsouris and Sayne (2013) provide some evidence to support its classification as a CRAVED product. This is because, stolen crude oil is; - concealable in mobile or static storages, removable from pipelines, available in vulnerable pipelines, valuable as a marketable commodity, and disposable as well as transferrable through sale and transportation (Katsouris and Sayne, 2013). The enjoyable element however, does not directly apply to crude oil theft, albeit proceeds from the sales could be enjoyable.

In exploiting opportunity-based explanations of crime, crime fighting practices and research in the UK, the USA, Canada and Australia have embraced the use of space and time analytic methods in understanding crime patterns (Graham and Bennett, 1995 and Chainey et al. 
2008). According to Clarke (1995), this has bolstered the ability of policing agencies to efficiently allocate resources at well-established hotspots of crime in line with the concept of Situational Crime Prevention (SCP). SCP strategies are "measures that are (1) directed at highly specific forms of crime, (2) involve the management, design, or manipulation of the immediate environment in a systematic and permanent way as possible and (3) make crime more difficult and risky, or less rewarding and excusable as judged by a wide range of offenders" (Clarke, 1997). The application of such crime analytic techniques and prevention strategies are not well grounded in the Nigerian context, and particularly in efforts being made to contend with COT. Fundamentally though, the effectiveness of the SCP concept begins with having a thorough understanding of crime patterns in space and time.

\section{Study Aims}

Very little research has focused on the spatial and temporal patterns of crude oil theft (COT) and tested alternative explanations for any emerging patterns. The only exception to our knowledge is Anifowose et al (2012) who used spatiotemporal analysis to "quantify the magnitude and direction of correlation between pipeline interdiction and likely socioeconomic influences in Nigeria" (p.637). Their research did not find evidence in support of an association between pipeline breaches and socioeconomic factors such as poverty. However, the spatial unit of analysis used in their research were 5 aggregated regions (Anifowose et al, 2012), which makes the analysis necessarily crude and likely to have been considerably influenced by issues such as the Modifiable Areal Unit Problem (Fotheringham and Wong, 1991; and Holt et al, 1996) and the ecological fallacy (Robinson, 2009).

This research reported here therefore sought to improve upon existing knowledge of the criminality of COT and the crime patterns in space and time. The objectives were to establish 
whether COT in the Niger Delta significantly clusters and, to the degree to which this was possible, examine evidence for or against the distinct explanations for this theft outlined above. We therefore test the following hypotheses:

$\mathrm{H} 1:$ 'The spatial clustering of COT is statistically significant, demonstrating that it is influenced by the exploitation of known criminogenic opportunities'

$\mathrm{H} 2$ : 'There is a significant association between the frequency of COT incidences in the Niger Delta and the ratios of poverty and unemployment in locations with high COT occurrences'. H3: 'Variations in temporal patterns of the volumes of crude oil stolen are significantly correlated with variations of crude oil prices on the international market'.

\section{Methods}

\section{Data}

The geographical focus area of this research was three states in the Niger Delta (Bayelsa, Delta and Rivers) depicted in Figure 1 along with the structure of the oil infrastructure in this region. These states account for at least $95 \%$ of onshore oil production and have diverse socioeconomic and demographic characteristics, contributing towards enhancing the external validity of the findings (Lashari et al, 2013). Spatial and temporal data on incidences of COT for the period January 2012 to December 2014 were collated from reports primarily made by the oil companies under the auspices of the Oil Producers' Trade Section. Oil companies use diverse means to detect breaches along their pipelines. They use surveillance systems that sense drop in pressures in the pipelines, which are then physically investigated. Another means is the employment of surveillance contractors who daily monitor the entire lengths of pipelines to detect infractions. To protect their product, the companies proactively seek evidence of theft, so it is likely that the resulting statistics are fairly comprehensive. A total 1039 incidents were reported within the three year period studied. These incidences of 
COT were geocoded to achieve acceptable levels of accuracy, precision, consistency and reliability (Chainey and Ratcliffe, 2013). The monthly volume of crude oil stolen was also collated for the same period, expressed as number of barrels per day (bpd). Monthly prices of crude oil (in US Dollars) in the international market covering the same period was based on the United States Energy Information Administration data ${ }^{1}$.

(*put Figure 1 around here*).

Demographic and socioeconomic data were obtained from the Nigerian National Population Commission (NPC) and National Bureau of Statistics (NBS) respectively. Population data from the NPC were based on a 2006 national census ${ }^{2}$ which was extrapolated to get the current values for 2014 using World Bank country estimates for population growth. ${ }^{3}$ Data from the NBS provided the poverty ${ }^{4}$ and unemployment ${ }^{5}$ rates in each local government area (LGA) within the respective states. There are a total of 56 LGAs spread across the 3 states as follows: Bayelsa -8 (all have pipelines) ; Delta -25 ( 8 in the northern part do not have pipelines) and Rivers - 23 (only one does not have a pipeline). The approximate size of the LGAs are between $100-600$ square $\mathrm{km}$, depending on the population amongst other considerations such as demography. There are a small number of outliers, such as Southern ljaw LGA with a size of $2674 \mathrm{sq} \mathrm{km}$ and a population of about 380,000 people. On average, the population counts are between 90,000 and 400,000 residents depending on the extent of urbanization in the respective LGAs.

\section{Spatial Analysis}

The spatial pattern of COT incidences was analysed using ArcGIS 10.2 software. Locations of COT were geocoded and aggregated to spatial units - in this case LGA within the states. The

\footnotetext{
${ }^{1}$ https://www.eia.gov/dnav/pet/hist/LeafHandler.ashx?n=PET\&s=RBRTE\&f=M

${ }^{2}$ http://www.population.gov.ng/index.php/censuses

${ }^{3} \mathrm{http}: / /$ data.worldbank.org/indicator/SP.POP.GROW?locations=NG

${ }^{4}$ http://www.nigerianstat.gov.ng/pdfuploads/Nigeria\%20Poverty\%20Profile\%202010.pdf

${ }^{5} \mathrm{http}: / /$ www.nigerianstat.gov.ng/report/375
} 
aggregated data was subsequently used to produce a thematic map showing the number of theft cases recorded within LGA. Moran's / global spatial autocorrelation test was conducted using ArcGIS 10.2 to further examine the extent of spatial clustering within the LGAs. CrimeStat III software was used to undertake a nearest neighbour analysis (NNA) to determine spatial clustering and to produce a Kernel Density Estimation (KDE) map to visualise the hotspot locations.

Further spatial tests were carried out to identify pipelines that were most susceptible to COT using the principle of 'hot routes' (Tompson et al, 2009) and enable analysis where pipelinesthe infrastructure in which COT events are possible - are used as the risk denominator. Locations of COT cases were therefore aggregated to pipelines and a heat map was produced showing the number of breaches per pipeline. However, considering that the pipelines differed in length, the relative risks of COT could be misrepresented using this metric alone. As a result, the average length of the pipelines ( $34 \mathrm{~km}$; SD $24 \mathrm{~km}$ ) was used to produce a rate map representing the rate of theft occurrences per $30 \mathrm{~km}$ of pipeline length. It was important to also determine if there was spatial autocorrelation of COT incidents on the individual pipelines. A Moran's I local indicators of spatial association (LISA) test was therefore conducted to designate the levels of significant local clustering of COT along individual pipelines.

\section{Regression Test and Correlation Analysis}

Multiple linear regression was used to investigate the connections between the unemployment, poverty ratios and incidences of COT. This demographic data is detailed at the LGA level in Appendix 1. Based on the population of each LGA, the total number in poverty/unemployed was divided by the economically active population to produce ratios of 
poverty and unemployment using the rates outlined in data from the NBS (Cantor and Land, 1985). Appendix 1 also includes the number of COT cases per LGA as well as the total length of pipelines per LGA. These were used for tests to determine the influence of the predictors (unemployment, poverty and pipeline lengths) on COT at LGA level. Both the dependent variable and predictors were measured at the ratio level. A Shapiro-Wilk normality test for the distributions of the unemployment ratio $(W=0.925, p<0.001)$ and poverty ratio $(W=0.680$, $p<0.001$ ) indicated that the data significantly deviates from normal distributions (Shapiro and Wilk, 1965) hence non-parametric regression was used. Tests for homoscedasticity were done by plotting the standardized residuals against the unstandardized predicted values. Some heteroscedasticity was observed on the plot but, it was not significant enough to invalidate the regression (Korendijk et al, 2008).

Non-parametric Spearman correlation tests were used to test the association between the variations in volumes of crude oil stolen and the market price (Sidebottom et al, 2014). A time series analysis was not appropriate in this case, as the data were not normally distributed. A Shapiro-Wilk normality test for the distribution of volume of crude oil stolen $(W=0.926, p<0.05)$ and the distribution of the prices of crude oil for the three year $(W=0.769$, $p<0.001$ ) demonstrated the data significantly deviates from normal distributions (Shapiro and Wilk, 1965). Furthermore, the mean as well as variance of each year's data did not have 'stationarity' (Allard, 1998). The assumptions of monotonic relationship between the variables were met, and the data was measured on ratio scales. 


\section{Results}

Figure 2 depicts the temporal pattern of COT cases for a 36-month period (2012-2014). It shows a steady rise in theft cases from 2012 through 2013 into 2014. A steep drop was experienced from May 2014, albeit with some occasional rises thereafter.

(*put Figure 2 around here*).

Figure 3 examines the monthly variation in the volume of crude oil stolen by year of study. For 2012 , a mean of $1,702,504$ (standard deviation of 976,683 ) barrels of crude oil per day (bpd), were stolen in each month. For 2013, the median was 1,707,492 bpd (SD 480,795) and for 2014 the mean was 1,067,723 bpd, SD 427,108. It is apparent that though 2012 had the lowest number of incidents of theft (Figure 2), it also had $50 \%$ of volumes of oil stolen falling within a range of $1,841,663 \mathrm{bpd}$ or above (Figure 3 ). The mean volume of barrels stolen per day was substantially smaller for the months during 2014 , demonstrating that the volume of oil taken per theft, and the theft of very large amounts of oil in one-time period appeared to have more recently reduced.

$\left({ }^{*}\right.$ put Figure 3 around here*)

Figure 4 shows variation in the monthly prices of crude oil per barrel in the international market by year. In 2012 the cost of oil had monthly mean of \$105.01 (SD \$7.44), for 2013 the mean was $\$ 104.07$ (SD \$3.44) and in 2014 , the mean was $\$ 96.25$, (SD \$14.54). This shows a small but noticeable more recent drop in the value of oil on the market.

(*put Figure 4 around here*) 


\section{Spatial Distribution of Crude Oil Theft}

Figure 5 is a thematic map that depicts the amount of COT incidences within the 56 LGAs located in the 3 states being studied. The LGA with the highest amounts of theft are labelled. Southern ljaw accounted for about $42.22 \%$ of incidents, while Brass and Nembe LGA experienced $10.48 \%$ and $10.17 \%$ of theft respectively. This provides evidence that the theft of crude oil is spatially concentrated in the Niger region.

(*put Figure 5 around here*)

Since COT requires the availability of oil pipeline infrastructure, theft cases per pipeline were investigated. Mapping this data revealed that one pipeline in Southern Ijaw LGA accounted for about $46.72 \%$ of all the theft cases recorded. This suggests that certain existing environmental as well as situational features could have made this particular pipeline more susceptible and attractive than others. There could be several contributory factors, nonetheless this provides some evidence in support of the proposition that offenders behind COT rationalise their actions based on envisaged costs and benefits (Clarke and Cornish, 1985). As mentioned earlier however, the length of the different pipelines are not even which means the longer pipelines could experience higher levels of COT on the basis of their length alone. A rate map (Figure 6) was therefore produced which depicts the amount of theft per $30 \mathrm{~km}$ of pipeline length. It is apparent that some pipelines experience more theft than others within $30 \mathrm{~km}$ of pipeline length, signifying substantial levels of clustering of COT based on exploitable environmental and situation conditions. Interestingly the pipeline in Southern ljaw LGA has the greatest rate of COT per $30 \mathrm{~km}$ as well as the largest number of COTs for a single pipeline showing high concentration of offences across several metrics. Appendix 2 gives the rate of theft per $30 \mathrm{~km}$ of pipeline within each of the respective LGAs.

(*put Figure 6 around here*). 


\section{Spatial Clustering of Crude Oil Theft}

The first research question proposed above was to investigate whether the rate of COT was influenced by exploitation of criminal opportunities, which we argued would be evident if there was statistically significant spatial clustering. Firstly, a nearest neighbour analysis test produced a nearest neighbour index of 0.1893 with standard error of 55.55 . This spatial clustering was statistically significant $(z=-42.61, p<0.001)$ which implied that locations where COT occurred were closer to each other than would be expected based on chance, (Ratcliffe, 2005). Likewise, a Moran index to determine the existence of positive spatial autocorrelation between vulnerable pipelines was statistically significant $(z=6.34, p<0.0001)$. This signified that pipelines which experienced high cases of COT and were surrounded by other pipelines that recorded high theft cases also. The hotspots as well as hot pipelines of COT (see Figure 7 for a visualisation), reveal spatial patterns which support the proposition that COT is likely a resultant effect of the convergence of offenders - crude oil thieves, and the target - crude oil, in places with vulnerable oil infrastructure (Clarke and Webb, 1999; Clarke and Eck, 2005). (*put Figure 7 around here*).

Further investigations into the spatial clustering of COT incidences revealed that locations where COT clustered, were positively (Moran's $I=0.20$ ) spatially auto-correlated with other locations of СОT. Based on the statistically significant z-score of 4.83 , there is less than $1 \%$ likelihood $(p<0.001)$ that this clustered pattern of COT incidences could have happened by chance. Tests were also carried out to investigate significant spatial clusters within the pipelines themselves, which controls for the dependency of this crime on the physical pipeline infrastructure. The Moran index was $0.74(z=6.34, p<0.0001)$ which signified existence of a statistically significant positive spatial autocorrelation between the most vulnerable pipelines, and hence the existence of clusters of high theft pipelines. The crime pattern is 
clearly not ubiquitous, and it therefore supports this research's propositions that the crime is influenced by infrastructure-enabled targeted criminality.

\section{Relationships between Crude Oil Theft, Poverty and Unemployment}

The second research aim of this paper was to establish if there was any significant association between the frequency of COT incidences in the Niger Delta and the ratios of poverty and unemployment within each LGA. The total lengths of pipelines within each LGA was also added as a predictor to control for the disproportional lengths of pipelines across the LGAs. A linear regression demonstrated that in combination, the poverty and unemployment ratios including the lengths of pipelines accounted for $26.2 \%$ of the variation in COT across the LGAs demonstrating the weak explanatory value of these variables $\left[R=0.550, R^{2}=0.303, F(3,52)\right.$ $=7.518, p<0.001]$. No significant positive associations were found for either the unemployment ratio $(\beta=-0.015, t=-0.13, n s)$ or the poverty ratio $(\beta=-.192, t=-1.540, n s)$. There was however a stronger positive but still insignificant association between the length of pipeline per LGA and COT $(\beta=0.457, t=3.69, n s)$. A more parsimonious model using the length of pipeline per $L G A$ as a single predictor of $C O T\left[R=0.518, R^{2}=0.268, F(1,54)=19.778, p<0.001\right]$ recorded a significant positive association between the two variables $(\beta=0.518, t=4.45$, $p<0.001)$. This result supports findings of a similar research by Anifowose et al (2012) that there is no correlation between socioeconomic factors like poverty/unemployment and pipeline interdiction crimes in Nigeria. It further shows that when disaggregated, relationships between crime and socioeconomic indicators are relatively weak (Janko and Popli, 2015). This challenges perspectives advanced by Onuoha (2009); Garuba (2010) and Oteh and Eze (2012) that use aggregated socioeconomic indicators to postulate that COT might be influenced by unemployment and poverty rates. More importantly though, it 
supports views that argue for more attention in controlling the proximal causes of crime as against the distal ones (Wortley, 2012) and the significance of the exposure variable alone (length of available pipeline) in predicting levels of COT strengthens the case for the view that this type of crime is at least in part opportunity related.

\section{Relationships between Crude Oil Theft and International Market Price}

The final research aim was to establish whether variations in temporal patterns of volumes of crude oil stolen were significantly correlated with variations in crude oil prices in the international market. A Spearman Rho's test was run to determine the measure of association between the 36 months' variations of the volume of crude oil stolen and the price. There was a moderate, statistically significant positive association $\left(r_{s}=0.528, p=0.001, n=36\right)$ between the volume of crude oil stolen and the price in the 36 month period. This correlation provides evidence in support of the proposition that COT could be influenced by rationalised cost and benefit calculations (Clarke and Cornish, 1985). Offenders therefore appear likely to engage in COT based on theft opportunities, commodity prices, as well as market availability. There is therefore evidence in support of the price-theft association within the context of COT.

\section{Discussion}

\section{Application of SCP}

The research findings suggest that a problem orientated strategy with a focus on the hotspots of COT could be useful in addressing this type of crime. For instance, there are contiguous clusters of LGAs like Brass, Nembe and Southern ljaw which all had high incidences of COT of (103, 100 and 415 respectively) most likely in response to favourable situational conditions for theft (See Appendix 1). As expected, in general, in areas with more available pipeline there 
is more COT, demonstrating that overall exposure to oil infrastructure is a significant facilitator. However, the fact that particular situational circumstances that are as yet unmeasured are key is supported by the fact that some LGAs with similar terrains and more pipelines, like Warri South West, did not record relatively high incidences (See Appendix 1). It is also evident that the rate of theft for every $30 \mathrm{~km}$ length of pipeline is quite high in some LGAs (e.g. Ekeremor, Degema and Akuku Toru) demonstrating a significant spatial clustering of COT onto certain regions of the pipeline (See Appendix 2).

The most general implication of the research findings reported above is that understanding the spatial, temporal and spatiotemporal patterns of COT, is foundational in efforts to curtail the crime. It enables better appreciation of the problem and supports implementation of deft response initiatives based on principles of SCP. These principles articulate how response can be proactive by manipulating environmental conditions by increasing the efforts and risks involved in committing crimes, as well as reducing the rewards and removing excuses (Clarke, 1995 and Clarke, 1997). There is recent evidence of some movement towards such approaches. For instance, the Nigerian National Petroleum Corporation has initiated policies to enhance surveillance of critical oil infrastructure using drones (Alegbe, 2015). With a better understanding of the significant spatial clustering and spatiotemporal pattern of COT, the use of drones at well-established hotspots will be most effective in increasing the efforts and risk involved in COT. The challenges to the implementation of SCP techniques in stemming COT are no doubt daunting considering the terrain, as well as the complex operating environment exacerbated by tense relationships between the oil companies and host communities. It also seems likely in this context that monitoring will be mainly undertaken by companies themselves rather than local police or other stakeholders. The legitimacy of the companies as crime preventers will therefore be a key factor in the success or failure of interventions. 
Another possibility which might enhance prevention is to look at the application of market reduction approaches as a viable strategy since there is evidence in support of the price-theft hypothesis. For crimes like COT however, the application of MRAs could be quite challenging because the black markets are not clear. As mentioned earlier, it is also likely that the structure of the market is not as widely distributed as for other forms of theft. Given the 'specialist' nature of oil sales, it is less likely that thieves rely on casual interactions with 'nearby' buyers but more on established relationships or steal oil for their own consumption, making general market regulation a less impactful strategy.

A further challenge comes with the difficultly of identifying illegally sourced crude oil. Nevertheless, Clarke (2004) argues that "technology changes everything, crime included" (p.55). The efficacy of technological approaches to crime reduction have been well-evidenced in stemming vehicle theft for example (Farrell et al , 2011). Since crude oil types have different characteristics and spectral signatures, finger printing technologies can be used to identify crude oil from their origins (Hegazi et al, 2005). Doing this would ensure that refineries and markets through due diligence became better aware of the source of their crude oil. In turn this could lead to more stringent regulation of crude oil traders and a reduction in readily available channels for the onwards sale of stolen crude oil.

\section{Research Limitations}

This research had some limitations that should be articulated. First, the use of socioeconomic data of the LGA within which the oil pipes are located presupposes that COT offenders are located and motivated from within these communities. However, whilst this cannot be tested with the available data, this does not appear to be an unrealistic assumption, as it is 
considered impracticable to execute such crime without some local community support and connivance.

Second, this research was unable to assess the different environmental and situational circumstances that specifically create the opportunities for COT, due to lack of information at the micro-setting level. For example, some locations of theft are highly likely to be selected because of inadequate security measures amongst other criminogenic factors, which would make them vulnerable to repeat victimisation. An examination of these factors would have enhanced the findings reported here by providing more information about the specific characteristics of locations routinely victimised. A possibility that was explored was using proximity to features such as settlements or roads to look for micro-level commonalities across COT locations. Unfortunately the lack of geo-referenced micro-level data sets on roads and settlements in this area of Nigeria precluded this further analysis. Neither is the mangrove terrain conducive to make this an easily achievable geo-coding task.

\section{Future Research}

This research has brought to the fore some issues which form plausible areas for future research. The knowledge of where COT clusters and of its spatiotemporal pattern could be complemented with an understanding of where the crime might occur in the future. Research could therefore explore the usefulness of prospective hotspot mapping to predict locations likely to be targets of COT (e.g. Bowers et al, 2004). Future qualitative research could use interviews and questionnaires to sample local perspectives on COT, and question arrested COT offenders to get their views on how they rationalise the cost and benefits of their actions. This could also probe for further understanding of the role of political economics (Collier 2008) and the publics' belief about the equity of resource exploitation. Having identified 
some hotspots in this research, and identified SCP methods as a crime prevention strategy for COT, it would also be helpful to investigate whether in this context for this crime type, security responses in one location could lead to crime displacement to another (Guerette and Bowers, 2009).

\section{Conclusion}

The central aim of this research was to investigate the spatial and temporal pattern of COT. This is considered critical to efforts aimed at curtailing the crime, while also contributing to broader knowledge on the form of this type of criminality. The research results identified locations and pipelines where COT significantly clusters and further established that the crime patterns were spatially auto-correlated. The significance of this spatial clustering supports the proposition that offenders are likely to be exploiting favourable environmental and situational circumstances. The findings also suggested that COT is driven at least in part by the market value of crude oil, indicating a need to be vigilant whilst prices are unusually high. Spatially and temporally specific SCP techniques target hardening and improving surveillance in vulnerable situations should reap crime reduction benefits. There is less support here for evidence of theft levels being driven by unemployment and poverty rates in the nearby community. 


\section{References}

Alegbe, O, 2015. NNPC Seeks to End Oil Theft in Eight Months Using Drones. Thisday Newspapers http://www.thisdaylive.com/articles/nnpc-seeks-to-end-oil-theft-in-eightmonths-using-drones/219141/, accessed 8 September 2015.

Allard, R, 1998. Use of time-series analysis in infectious disease surveillance. Bulletin of the World Health Organization, 76(4), pp. 327.

Anifowose, B., Lawler, D. M., Van der Horst, D, and Chapman, L, 2012. Attacks on oil transport pipelines in Nigeria: A quantitative exploration and possible explanation of observed patterns. Applied Geography, 32(2), pp.636-651.

Ashby, P.J and Bowers, K.J, 2015. Concentrations of railway metal theft and the locations of scrap-metal dealers. Applied Geography, 63, pp.283-291.

Asuni, J. B, 2009. Blood oil in the Niger Delta (Vol. 229). Washington, DC: United States Institute of Peace.

Baker, S. A, 2003. An analysis of timber trespass and theft issues in the Southern Appalachian region.

Bowers, K. J., Johnson, S. D., and Pease, K, 2004. Prospective hot-spotting the future of crime mapping? British Journal of Criminology, 44(5), pp.641-658.

Cantor, D., and Land, K. C, 1985. Unemployment and crime rates in the post-World War II United States: A theoretical and empirical analysis. American Sociological Review, pp.317332.

Chainey, S., and Ratcliffe, J, 2013. GIS and crime mapping. John Wiley and Sons.

Chainey, S., Tompson, L., and Uhlig, S, 2008. The utility of hotspot mapping for predicting spatial patterns of crime. Security Journal, 21(1), pp.4-28.

Clarke, R. V, 1995. Situational crime prevention. Crime and justice, 91-150.

Clarke, R.V.G. ed., 1997. Situational crime prevention (pp. 53-70). Monsey, NY: Criminal Justice Press.

Clarke, R., 1999. Hot Products: Understanding, Anticipating and Reducing Demand for Stolen Goods. Police Research Series Paper 112. London: Home Office. 
Clarke, R. V., 2004. Technology, criminology and crime science. European Journal on Criminal Policy and Research, 10(1), pp.55-63.

Clarke, R. V., and Eck, J. E., 2005. Crime analysis for problem solvers. Washington, DC: Centre for Problem Oriented Policing.

Clarke, R. V. G., and Webb, B, 1999. Hot products: Understanding, anticipating and reducing demand for stolen goods.

Clarke, R. V., and Cornish, D. B, 1985. Modelling offenders' decisions: A framework for research and policy. Crime and justice, pp.147-185.

Collier, P.,2008. The bottom billion: Why the poorest countries are failing and what can be done about it. Oxford University Press.

Davidheiser, M., and Nyiayaana, K.,2011. Demobilization or remobilization? The amnesty program and the search for peace in the Niger Delta. African Security, 4(1), pp.44-64.

Davis, S.,2009. The potential for peace and reconciliation in the Niger Delta.

Department of Petroleum Resources. (2015). Upstream Statistics. Retrieved 11 June 2015 from https://dpr.gov.ng/index/dpr-operations/upstream-regulation/statistics/.

Farrell, G., Tilley, N., Tseloni, A., and Mailley, J.,2011. The crime drop and the security hypothesis. Journal of Research in Crime and Delinquency, 0022427810391539.

Fotheringham, A. S., and Wong, D. W.,1991. The modifiable areal unit problem in multivariate statistical analysis. Environment and planning A, 23(7), pp.1025-1044.

Garuba, D. S., 2010. Trans-Border Economic Crimes, Illegal Oil Bunkering and Economic Reforms in Nigeria. Policy Brief Series, 15.

Graham, J., and Bennett, T.,1995. Crime prevention strategies in Europe and North America. Helsinki, Finland: European Institute for Crime Prevention and Control.

Guerette, R. T., and Bowers, K. J.,2009. Assessing the extent of crime displacement and diffusion of benefits: a review of situational crime prevention evaluations*. Criminology, 47(4), pp.1331-1368.

Hegazi, E., Hamdan, A., and Mastromarino, J.,2005. Remote fingerprinting of crude oil using time-resolved fluorescence spectra. Arabian Journal for Science and Engineering, 30(1), pp.312. 
Holt, D., Steel, D. G., Tranmer, M., and Wrigley, N.,1996. Aggregation and ecological effects in geographically based data. Geographical analysis, 28(3), pp.244-261.

Ikelegbe, A.,2005. The economy of conflict in the oil rich Niger Delta region of Nigeria. Nordic Journal of African Studies, 14(2), pp.208-234.

Janko, Z., and Popli, G.,2015. Examining the link between crime and unemployment: a timeseries analysis for Canada. Applied Economics, (ahead-of-print), pp.1-13.

Johnson, S. D. (2010). A brief history of the analysis of crime concentration. European Journal of Applied Mathematics, 21(4-5), 349-370. doi:10.1017/s0956792510000082

Katsouris, C., and Sayne, A.,2013. Nigeria's Criminal Crude: International Options to Combat the Export of Stolen Oil. Chatham House, pp.1-68.

Kayode-Adedeji, D. (2015). Nigeria losing 400,000 barrels of oil to thieves daily - Osinbajo. Premium Times Newspapers. Retrieved 14 June 2015 from http://www.premiumtimesng.com/news/headlines/185016-nigeria-losing-400000-barrelsof-oil-to-thieves-daily-osinbajo.html

Korendijk, E. J., Maas, C. J., Moerbeek, M., and Van der Heijden, P. G.,2008. The influence of misspecification of the heteroscedasticity on multilevel regression parameter and standard error estimates. Methodology, 4(2), pp.67-72.

Lashari, T. A., Alias, M., Kesot, M. J., and Akasah, Z. A.,2013. An Affective-Cognitive Teaching and Learning Approach for Enhanced Behavioural Engagements among Engineering Students. Engineering Education, 8(2), pp.65-78.

Obi, C. I.,2010. Oil extraction, dispossession, resistance, and conflict in Nigeria's oil-rich Niger Delta. Canadian Journal of Development Studies/Revue canadienne d'études du développement, 30(1-2), pp.219-236.

Okonjo-Iweala, N.,2014. Competing in an Uncertain World, Thisday Newspaper http://www.thisdaylive.com, accessed 5 December 2014.

Oluwaniyi, O. O.,2011. Post-Amnesty programme in the Niger Delta: Challenges and prospects. Conflict trends, (4), pp.46-54.

Onuoha, F. 2007. Poverty, pipeline vandalisation/explosion and human security: integrating disaster management into poverty reduction in Nigeria. African Security Studies, 16(2), 94108 
Onuoha, F. C.,2008. Oil pipeline sabotage in Nigeria: dimensions, actors and implications for national security. African Security Studies, 17(3), pp.99-115.

Onuoha, F. C.,2009. Why the poor pay with their lives: oil pipeline vandalisation, fires and human security in Nigeria. Disasters, 33(3), pp.369-389.

Oteh, C. O., and Eze, R. C.,2012. Vandalization of oil pipelines in the Niger delta region of Nigeria and poverty: an overview. Studies in Sociology of Science, 3(2), pp.13-21.

Pires, S., and Clarke, R. V., 2012. Are parrots CRAVED? An analysis of parrot poaching in Mexico. Journal of research in crime and delinquency, 49(1), pp.122-146.

Posick, C., Rocque, M., Whiteacre, K., and Mazeika, D.,2012. Examining metal theft in context: An opportunity theory approach. Justice Research and Policy, 14(2), pp.79-102.

Ratcliffe, J. H.,2005. Detecting spatial movement of intra-region crime patterns over time. Journal of Quantitative Criminology, 21(1), pp.103-123.

Renouard, C., and Lado, H.,2012. CSR and inequality in the Niger Delta (Nigeria). Corporate Governance: The international journal of business in society, 12(4), pp.472-484.

Robinson, W. S.,2009. Ecological correlations and the behaviour of individuals. International journal of epidemiology, 38(2), pp.337-341.

Shapiro, S. S., and Wilk, M. B.,1965. An analysis of variance test for normality (complete samples). Biometrika, pp.591-611.

Schneider, J. L.,2008. Reducing the illicit trade in endangered wildlife the market reduction approach. Journal of Contemporary Criminal Justice, 24(3), pp.274-295.

Sherman, L.W., Gartin, P.R. and Buerger, M.E., 1989. Hot spots of predatory crime: Routine activities and the criminology of place. Criminology, 27(1), pp.27-56.

Sidebottom, A.,2013. On the application of CRAVED to livestock theft in Malawi. International Journal of Comparative and Applied Criminal Justice, 37(3), pp.195-212.

Sidebottom, A., Belur, J., Bowers, K., Tompson, L., and Johnson, S. D.,2011. Theft in pricevolatile markets: on the relationship between copper price and copper theft. Journal of Research in Crime and Delinquency, 48(3), pp.396-418.

Sidebottom, A., Ashby, M., and Johnson, S. D.,2014. Copper Cable Theft Revisiting the PriceTheft Hypothesis. Journal of Research in Crime and Delinquency, 51(5), pp.684-700. 
Stevenson, R. J., Forsythe, L. M., and Weatherburn, D.,2001. The stolen goods market in New South Wales, Australia: An analysis of disposal avenues and tactics. The British Journal of Criminology, pp.101-118.

Sutton, M.,1995. Supply by Theft: does the market for second-hand goods play a role in keeping crime figures high? The British Journal of Criminology, pp.400-416.

Sutton, M., Schneider, J., and Hetherington, S.,2001. Tackling theft with the market reduction approach. Home Office, Policing and Reducing Crime Unit, Research, Development and Statistics Directorate.

Sutton, M., and Simmonds, D.,2004. Tackling Burglary and Other Theft with the Market Reduction Approach. Criminal Justice Matters, 55(1), pp.28-29.

Sykes, G.M. and Matza, D., 1957. Techniques of neutralization: A theory of delinquency. American sociological review, 22(6), pp.664-670.

Tompson, L., Partridge, H., and Shepherd, N.,2009. Hot routes: Developing a new technique for the spatial analysis of crime. Crime Mapping: A Journal of Research and Practice, 1(1), pp.77-96.

Ufuoma, O. K., and Omoruyi, O.,2014. Political Economy Diagnosis of Crude Oil Theft in Nigeria: The Way Forward. Mediterranean Journal of Social Sciences, 5(2), 297.

Watts, M. (2008). Blood oil: The anatomy of a petro-insurgency in the Niger delta. Focaal, 2008(52), pp.18-38.

Watts, M.,2009. Crude politics: life and death on the Nigerian oil fields. Niger Delta Economies of Violence Working Papers, (25).

Wortley, R. K.,2012. Exploring the person-situation interaction in situational crime prevention. 
DEMOGRAPHIC DETAILS OF LGAS STUDIED

\begin{tabular}{|c|c|c|c|c|c|c|c|c|}
\hline Serial & State & LGA Name & Size (Sq Km) & Population & $\begin{array}{c}\text { Poverty Ratio } \\
\text { (Fraction of total } \\
\text { population in poverty) }\end{array}$ & \begin{tabular}{|c|} 
Unemployment \\
ratio \\
(Fraction of total \\
population \\
unemployed) \\
\end{tabular} & $\begin{array}{c}\text { Number of COT } \\
\text { Reports }\end{array}$ & $\begin{array}{c}\text { Total Length of } \\
\text { Pipelines/LGA(KM) }\end{array}$ \\
\hline 1 & Bayelsa & Southern ljaw & 2674 & 379412 & 0.439999262 & 0.213000643 & 415 & 126.93 \\
\hline 2 & Bayelsa & Ekeremor & 1801 & 317844 & 0.439998867 & 0.213000717 & 31 & 52.10 \\
\hline 3 & Bayelsa & Kolokuma/Opokuma & 361 & 93455 & 0.43999786 & 0.21300091 & 0 & 2.90 \\
\hline 4 & Bayelsa & Yenegoa & 704 & 415344 & 0.439999133 & 0.212999345 & 27 & 49.08 \\
\hline 5 & Bayelsa & Sagbama & 943 & 220319 & 0.439998366 & 0.213000241 & 9 & 17.90 \\
\hline 6 & Bayelsa & Brass & 1409 & 217085 & 0.439998157 & 0.212999516 & 103 & 49.77 \\
\hline $7 \mathrm{~B}$ & Bayelsa & Ogbia & 695 & 211755 & 0.439999056 & 0.213000874 & 8 & 49.08 \\
\hline 8 & Bayelsa & Nembe & 758 & 154409 & 0.440000259 & 0.212999242 & 100 & 95.49 \\
\hline 9 & Delta & Ndokwa West & 815 & 176878 & 0.539999322 & 0.212999921 & 1 & 4.50 \\
\hline 10 & Delta & Sapele & 450 & 205468 & 0.540001363 & 0.213001538 & 0 & 21.45 \\
\hline 11 L & Delta & Aniocha North & 407 & 122689 & 0.539999511 & 0.213001981 & 0 & 0.00 \\
\hline $12 \mathrm{~L}$ & Delta & Oshimili South & 267 & 176888 & 0.540002714 & 0.212999186 & 0 & 0.00 \\
\hline 13 & Delta & Warri South West & 1757 & 137398 & 0.540000582 & 0.213001645 & 27 & 138.23 \\
\hline 14 & Delta & Aniocha South & 870 & 167471 & 0.53999797 & 0.212998071 & 0 & 0.00 \\
\hline 15 & Delta & Patani & 217 & 74454 & 0.539997851 & 0.213004002 & 3 & 0.00 \\
\hline 16 & Delta & Warri South & 634 & 367813 & 0.539999946 & 0.212999541 & 2 & 40.88 \\
\hline 17 & Delta & Ukwuani & 409 & 140341 & 0.539999002 & 0.213002615 & 0 & 0.00 \\
\hline 18 & Delta & Ndokwa East & 1608 & 121701 & 0.539995563 & 0.212997428 & 4 & 17.60 \\
\hline 19 & Delta & Ughelli South & 784 & 250700 & 0.54 & 0.212999601 & 3 & 32.53 \\
\hline 20 & Delta & Ughelli North & 820 & 378090 & 0.540001058 & 0.21299955 & 4 & 55.01 \\
\hline 21 & Delta & Udu & 131 & 167984 & 0.539997857 & 0.213002429 & 1 & 6.20 \\
\hline 22 & Delta & Ethiope East & 380 & 236911 & 0.540000253 & 0.212999818 & 1 & 4.70 \\
\hline 23 & Delta & Ethiope West & 537 & 238997 & 0.540001113 & 0.213000594 & 1 & 28.89 \\
\hline 24 & Delta & Okpe & 445 & 151381 & 0.540001718 & 0.212998989 & 0 & 37.61 \\
\hline 25 & Delta & Bomadi & 129 & 101413 & 0.539999803 & 0.213000306 & 0 & 10.40 \\
\hline 26 & Delta & Oshimili North & 510 & 139758 & 0.53999771 & 0.212996752 & 0 & 0.00 \\
\hline 27 & Delta & Burutu & 1927 & 245205 & 0.540001223 & 0.213001366 & 1 & 8.80 \\
\hline 28 & Delta & Warri North & 1855 & 160520 & 0.540001246 & 0.213001495 & 5 & 84.80 \\
\hline 29 & Delta & Uvwie & 95 & 222510 & 0.539998202 & 0.213001663 & 0 & 15.20 \\
\hline 30 & Delta & Isoko North & 478 & 169256 & 0.539998582 & 0.213002789 & 0 & 35.46 \\
\hline 31 & Delta & Ika North East & 464 & 215544 & 0.540001113 & 0.213000594 & 0 & 0.00 \\
\hline 32 & Delta & Isoko South & 705 & 277238 & 0.539998582 & 0.213002789 & 6 & 39.65 \\
\hline 33 & Delta & Ika South & 435 & 196964 & 0.540002234 & 0.212998314 & 0 & 0.00 \\
\hline $34 \mathrm{P}$ & Rivers & Ahoada East & 342 & 196096 & 0.469999388 & 0.212997715 & 4 & 42.07 \\
\hline 35 & Rivers & Ogba/Egbema/Ndoni & 968 & 334004 & 0.470000359 & 0.213000443 & 60 & 84.70 \\
\hline 36 & Rivers & Andoni & 233 & 256932 & 0.469999844 & 0.213001884 & 1 & 19.22 \\
\hline 37 | & Rivers & Degema & 1009 & 294122 & 0.469998844 & 0.213000048 & 20 & 65.95 \\
\hline 38 & Rivers & Ogu/Bolo & 89 & 88757 & 0.470002366 & 0.212997285 & 0 & 0.00 \\
\hline 39 & Rivers & Ahoada West & 403 & 293232 & 0.469999864 & 0.212998581 & 31 & 52.89 \\
\hline 40 & Rivers & Oyigbo & 248 & 147765 & 0.470003045 & 0.213000372 & 10 & 43.02 \\
\hline 41 & Rivers & Omumma & 170 & 118357 & 0.469993325 & 0.212999654 & 5 & 1.48 \\
\hline 42 & Rivers & Akuku Toru & 1439 & 189940 & 0.470001053 & 0.212998842 & 22 & 118.06 \\
\hline 43 & Rivers & Bonny & 640 & 253465 & 0.469998519 & 0.213003109 & 10 & 67.68 \\
\hline $44 \mathrm{P}$ & Rivers & Abua/Odual & 704 & 332961 & 0.469997988 & 0.213000922 & 2 & 68.43 \\
\hline 45 & Rivers & Etche & 805 & 294678 & 0.470001154 & 0.212998595 & 14 & 10.10 \\
\hline 46 & Rivers & Port Harcourt & 109 & 634960 & 0.469999685 & 0.212999244 & 0 & 1.81 \\
\hline 47 | & Rivers & Obio/Akpor & 260 & 545111 & 0.469999688 & 0.213000655 & 7 & 54.86 \\
\hline 48 & Rivers & Ikwerre & 656 & 222748 & 0.470001975 & 0.212998545 & 7 & 35.85 \\
\hline 49 & Rivers & Gokana & 126 & 275665 & 0.470001632 & 0.213001288 & 25 & 22.23 \\
\hline 50 & Rivers & Tai & 159 & 141843 & 0.469998519 & 0.213003109 & 0 & 19.18 \\
\hline 51 & Rivers & Khana & 560 & 345357 & 0.539998202 & 0.213001663 & 4 & 17.26 \\
\hline 52 & Rivers & Okrika & 222 & 262074 & 0.470000839 & 0.213000908 & 1 & 15.10 \\
\hline 53 & Rivers & Asari Toru & 113 & 259129 & 0.469997569 & 0.212998159 & 2 & 9.40 \\
\hline 54 & Rivers & Eleme & 138 & 224239 & 0.469998528 & 0.213000415 & 3 & 23.40 \\
\hline 55 & Rivers & Opobo/Nkoro & 130 & 180190 & 0.469998335 & 0.212997392 & 0 & 10.54 \\
\hline 56 & Rivers & Emuohua & 833 & 237046 & 0.470001603 & 0.213000852 & 3 & 76.02 \\
\hline
\end{tabular}




\begin{tabular}{|c|c|c|c|}
\hline Serial & State & LGA Name & Rate Per 30 km/LGA \\
\hline 1 & Bayelsa & Southern ljaw & 134.21 \\
\hline 2 & Bayelsa & Ekeremor & 55.91 \\
\hline 3 & Bayelsa & Kolokuma/Opokuma & 5.80 \\
\hline 4 & Bayelsa & Yenegoa & 36.40 \\
\hline 5 & Bayelsa & Sagbama & 14.51 \\
\hline 6 & Bayelsa & Brass & 51.46 \\
\hline 7 & Bayelsa & Ogbia & 12.27 \\
\hline 8 & Bayelsa & Nembe & 162.44 \\
\hline 9 & Delta & Ndokwa West & 0.51 \\
\hline 10 & Delta & Sapele & 1.84 \\
\hline 11 & Delta & Aniocha North & 0.00 \\
\hline 12 & Delta & Oshimili South & 0.00 \\
\hline 13 & Delta & Warri South West & 31.92 \\
\hline 14 & Delta & Aniocha South & 0.00 \\
\hline 15 & Delta & Patani & 0.00 \\
\hline 16 & Delta & Warri South & 4.29 \\
\hline 17 & Delta & Ukwuani & 0.00 \\
\hline 18 & Delta & Ndokwa East & 2.53 \\
\hline 19 & Delta & Ughelli South & 13.08 \\
\hline 20 & Delta & Ughelli North & 6.36 \\
\hline 21 & Delta & Udu & 2.26 \\
\hline 22 & Delta & Ethiope East & 1.69 \\
\hline 23 & Delta & Ethiope West & 3.26 \\
\hline 24 & Delta & Okpe & 3.80 \\
\hline 25 & Delta & Bomadi & 3.79 \\
\hline 26 & Delta & Oshimili North & 0.00 \\
\hline 27 & Delta & Burutu & 3.84 \\
\hline 28 & Delta & Warri North & 28.75 \\
\hline 29 & Delta & Uvwie & 1.01 \\
\hline 30 & Delta & Isoko North & 3.67 \\
\hline 31 & Delta & Ika North East & 0.00 \\
\hline 32 & Delta & Isoko South & 18.80 \\
\hline 33 & Delta & Ika South & 0.00 \\
\hline 34 & Rivers & Ahoada East & 29.15 \\
\hline 35 & Rivers & Ogba/Egbema/Ndoni & 40.23 \\
\hline 36 & Rivers & Andoni & 4.21 \\
\hline 37 & Rivers & Degema & 55.30 \\
\hline 38 & Rivers & Ogu/Bolo & 0.00 \\
\hline 39 & Rivers & Ahoada West & 36.18 \\
\hline 40 & Rivers & Oyigbo & 17.77 \\
\hline 41 & Rivers & Omumma & 1.20 \\
\hline 42 & Rivers & Akuku Toru & 72.90 \\
\hline 43 & Rivers & Bonny & 44.56 \\
\hline 44 & Rivers & Abua/Odual & 12.94 \\
\hline 45 & Rivers & Etche & 1.26 \\
\hline 46 & Rivers & Port Harcourt & 0.49 \\
\hline 47 & Rivers & Obio/Akpor & 20.04 \\
\hline 48 & Rivers & Ikwerre & 13.47 \\
\hline 49 & Rivers & Gokana & 1.18 \\
\hline 50 & Rivers & Tai & 10.46 \\
\hline 51 & Rivers & Khana & 2.93 \\
\hline 52 & Rivers & Okrika & 4.63 \\
\hline 53 & Rivers & Asari Toru & 2.57 \\
\hline 54 & Rivers & Eleme & 16.62 \\
\hline 55 & Rivers & Opobo/Nkoro & 2.12 \\
\hline 56 & Rivers & Emuohua & 4.10 \\
\hline
\end{tabular}

'Italics indicate LGAs with a rate of theft of over 50 per $30 \mathrm{~km}$ of pipeline' 
Figure 1: The Oil Infrastructure in the Study Areas of Bayelsa, Delta and Rivers.

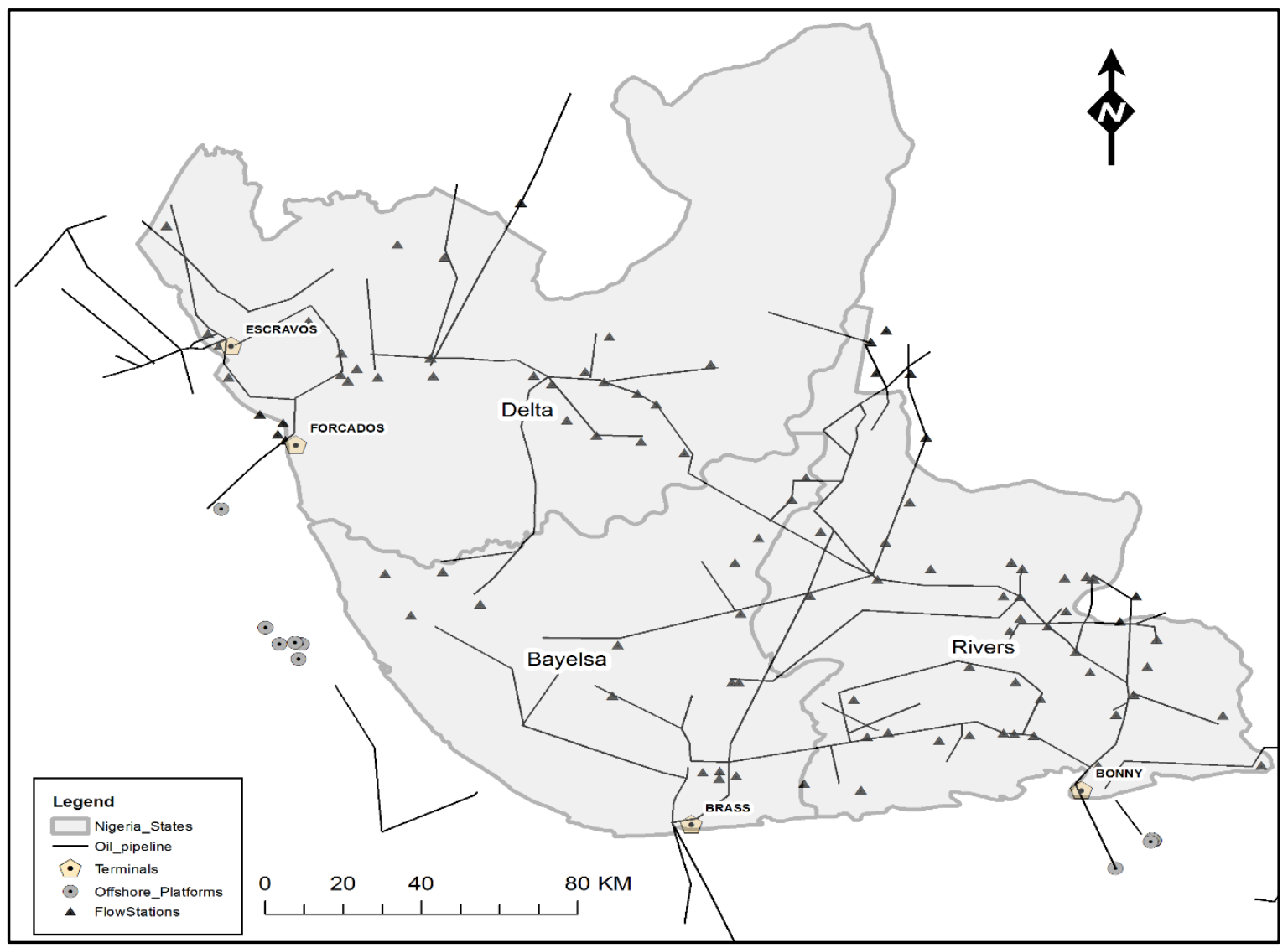

Figure 2: Temporal Pattern of Crude Oil Thefts in the Niger Delta.

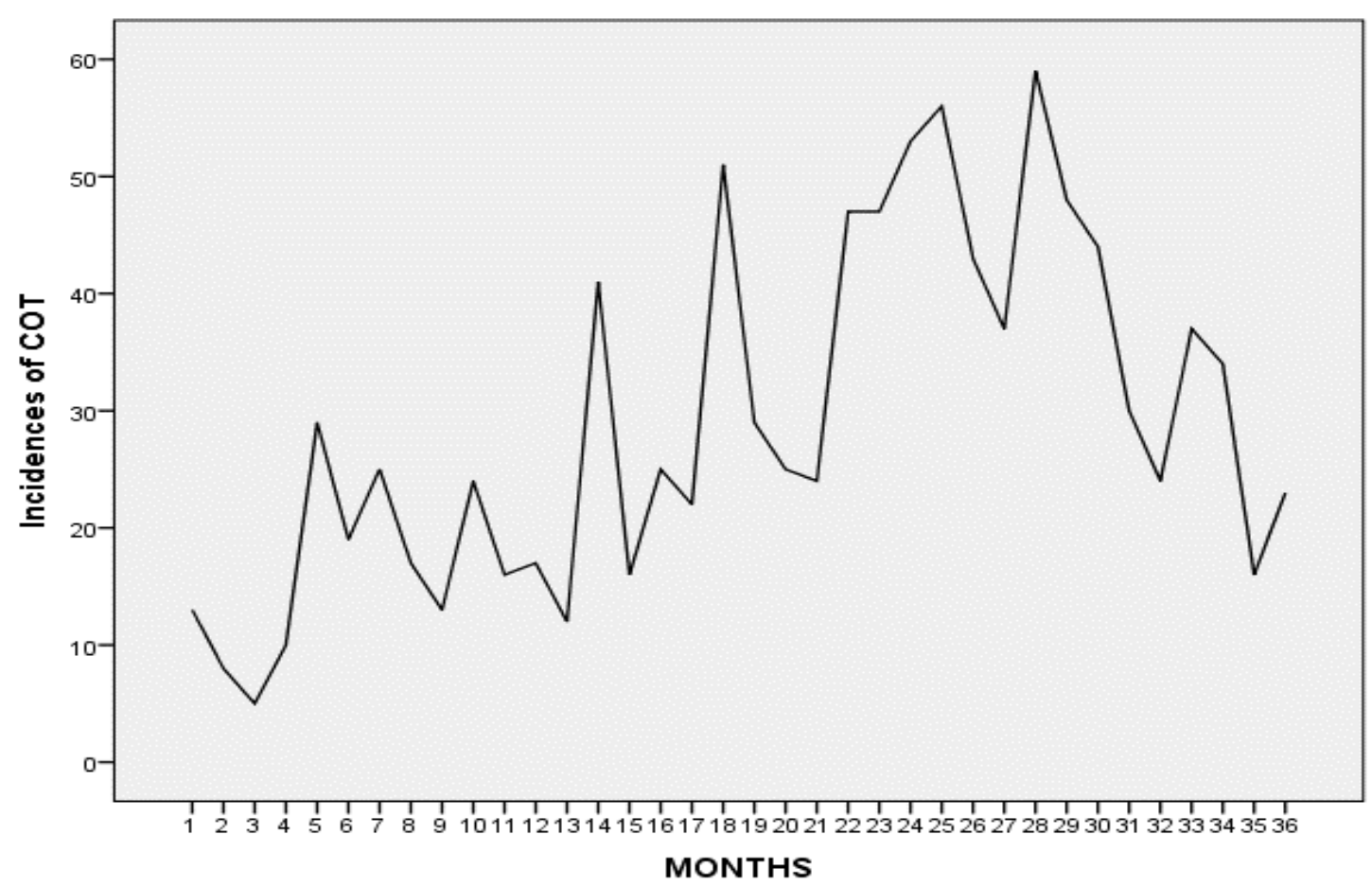


Figure 3: Volumes of Crude Oil Stolen Expressed as Average Number of Barrels Per Day.

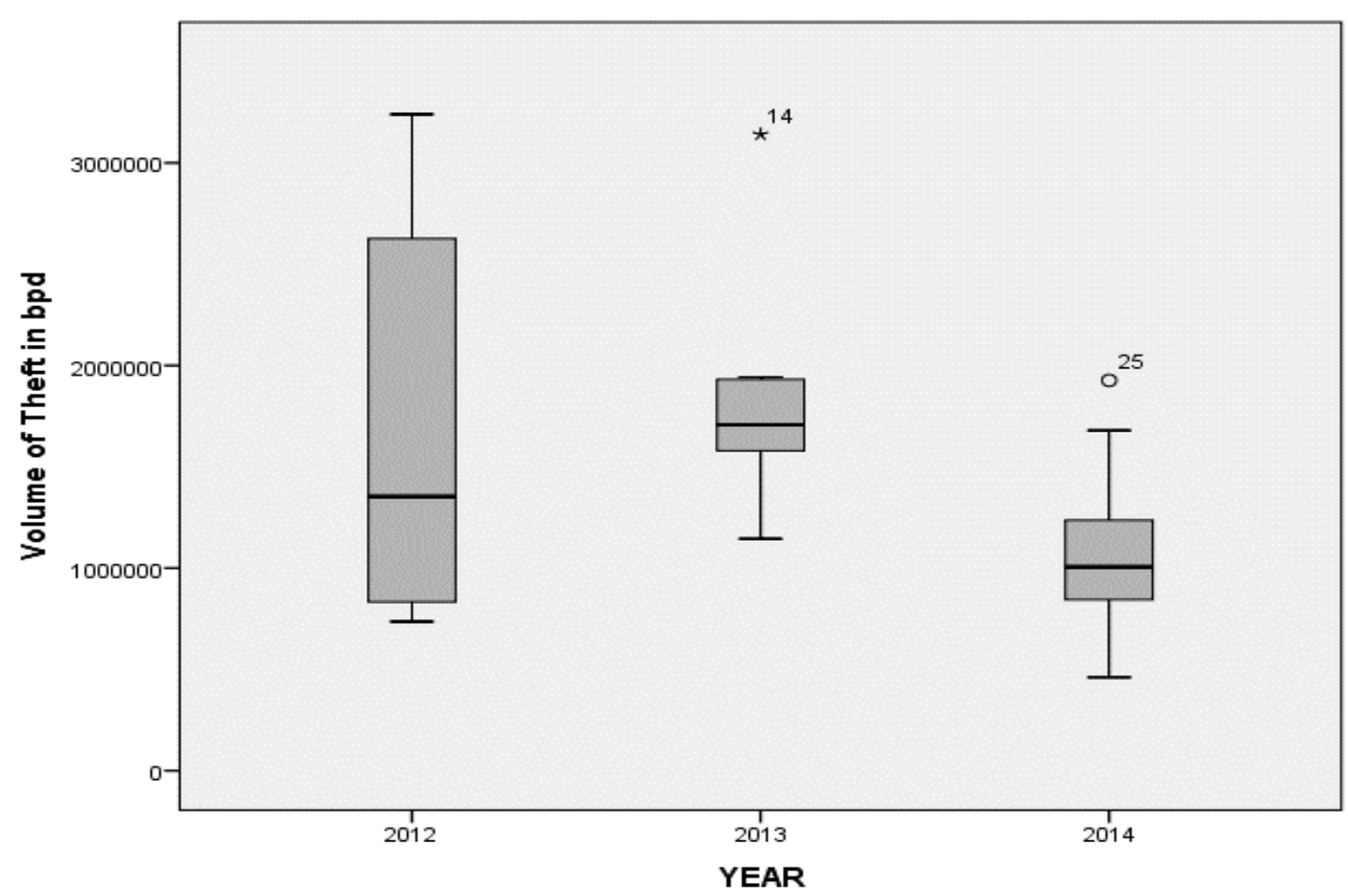

Figure 4: The Price of Oil Per Barrel in US Dollars for 2012 to 2014.

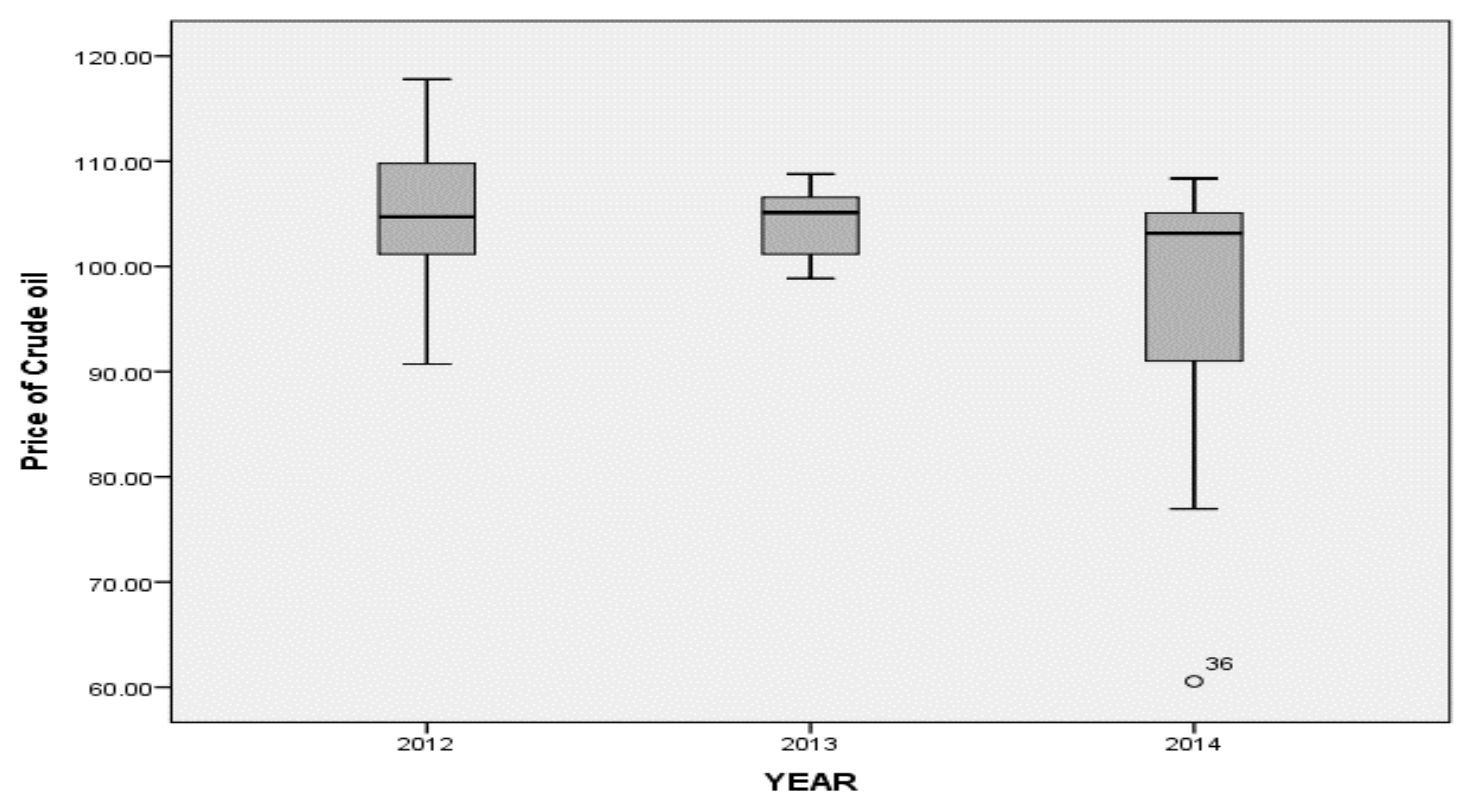


Figure 5: Number of Crude Oil Thefts by LGA.

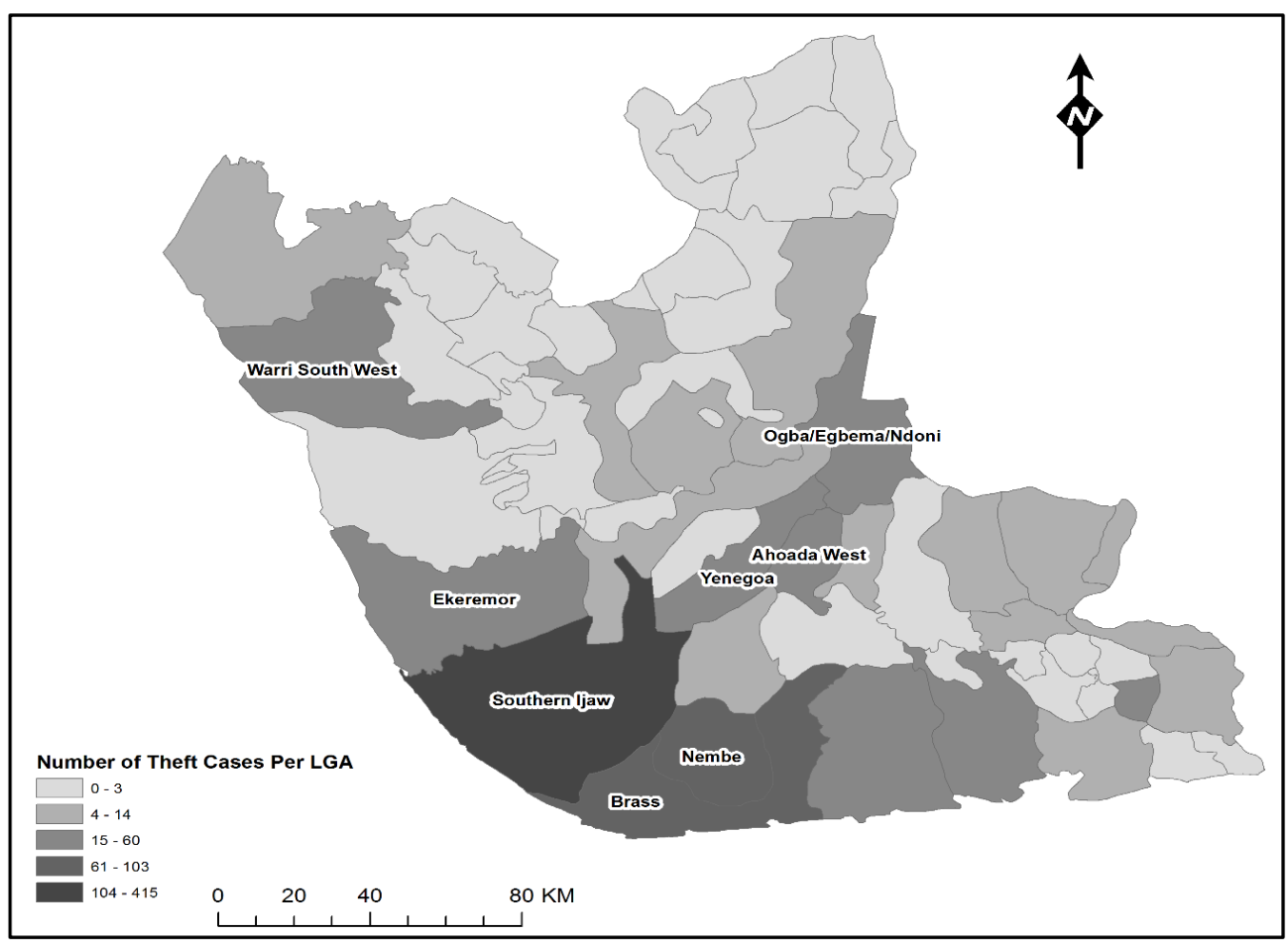

Figure 6: Rate Map of COT Incidents Per 30km of Pipeline Length.

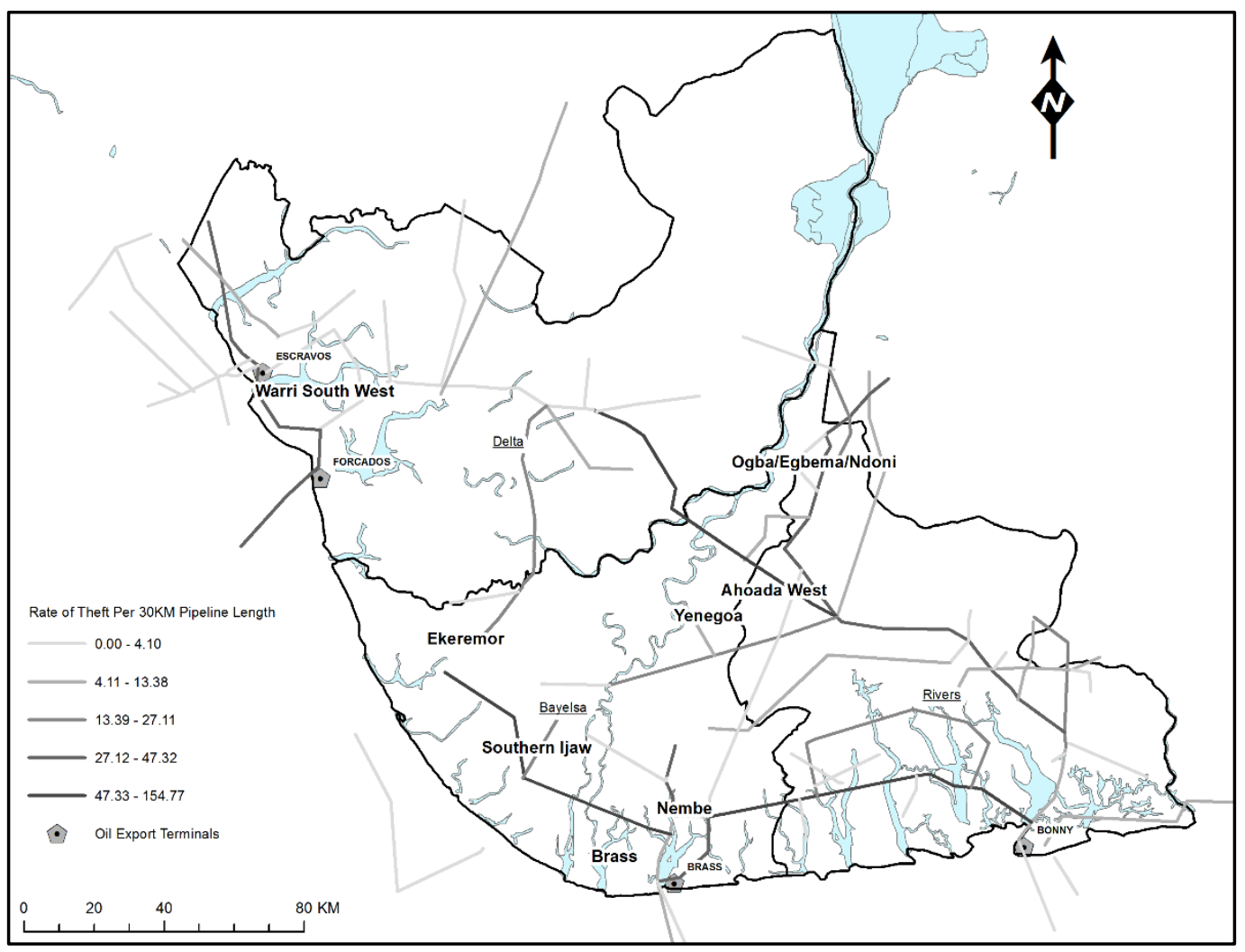


Figure 7: Map of Major Hotspots of Crude Oil Theft from Jan 2012 to Dec 2014

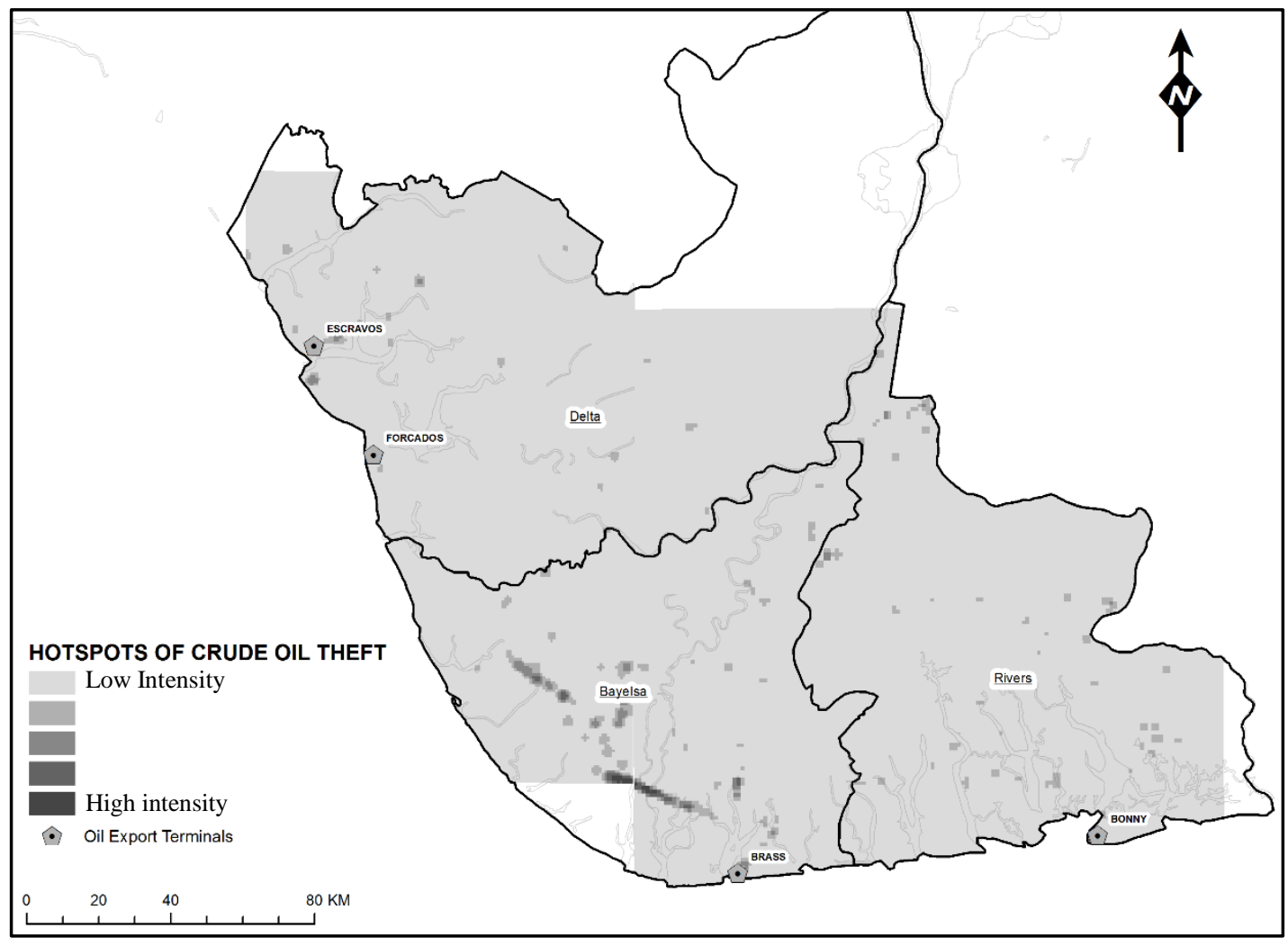

